AÜIFD Cilt XLIII (2002) Sayı 2 s. 1-18

\title{
Dinde Reformun Yöntemi ve Bir Örnek: Hırsızlık
}

\section{Hüseyin ATAY}

Prof. Dr., Ankara Üniversitesi İlâhiyat Fakültesi

"Method of Reform in Religion and a Case Study: Theft". This article (the first chapter of which was published in the issue XLIII of this Journal) deals with the problem of how to interpret the Qur'anic verses in a new method. In chapter one we gave the general and theoretical outline of this method, and now we are to give a case study, i.e. robbery. In theoretical level what we mean by reform is to demonstrate the mistake or blunder made in the past and to substitute it for a better and convenient one. The point to be underlined is that the new one must be a better one than the former. This requires to expose the grounds which make it obligatory to get rid of the past one and to replace it with a better one. This forms the theoretical base of reform. After outlining this base we applied it to a case study, that's robbery and we tried to show how it is tackled in the Qur'an.

Key Words: Religious reform, religious thought, ijtihad.

Öncelikle şunu belirtmeye gerek vardır. Yukarıda reform kavramının anlamları üzerinde durulmuştu. Bunlardan reformun iki şekilde olabileceği ortaya çıkmıştır: 
a. Eski bir fikrin yanlışlığını düzeltip, onun yerine yeni duruma daha uygun bir fikir koymak, geçmişteki yanlış, geçersiz bir hükmü kaldırıp yerine daha yararlı, doğru bir hükmü geçerli kılmak, uygulamaya koymak, diğer bir deyimle, geçmişteki bir hükmü veya fikri yanlışlamak, onun yanlışlığını tespit edip ona yanlış demek. Bu tutum, onun düzeltilmesi için ilk adım ve en önemli yöntemdir. Çünkü geçmişteki bir fikir veya hüküm yanlış olduğu görüldüğü ve anlaşıldığı hâlde, evirip çevirip doğrudan ona yanlış denemez de uydurma yorum ve açıklamalarla onun yanlışlı̆̆ı örtbas edilirse, o yanlış, yanlış olmaktan çıkar, sanki doğruluğu savunulmuş duruma gelir ve bir daha düzeltilemez ve herkes onu yürütmeye ve onun doğruluğuna inanılmış gibi davranmaya çalışır.

Bir yenilik ve ıslâh yapabilmenin ilk şartı, yanlış olanın ne olduğunu ve niçin değiştirilmek istendiğini bilmektir. Bu, sslahın, düzeltmenin gerekçesi ve aynı zamanda amaç nedeni olur. Geçmişin yanlışları düzeltilmezse, onun yanına yenisi konursa, hem yanlı̧, hem doğru bir arada bulunur, bu çelişik olduğu için, iki çelişik birbirini götürür. Elde sıfır kalır. Dinde de böyledir; ahlâkta da böyledir; idarede, siyasette ve ticarette de böyledir. Bunun için yanlışa yanlış deme yiğitliğini göstermeden ve ortaya koymadan, düzeltme olmaz. Yanlış, ister çok eski, ister az geçmiş, isterse yeni olsun, madem ki, yaşamla ilgilidir, kuşkusuz tespit edilerek kaldırılması ve düzeltilmesi şarttır. Yanlışın nasıl tespit edileceğini, düzeltileceğini, doğrusunun nasıl tespit edilmesi gerektiğini açıklarken anlatacağım.

b. Reform, bir şeyi, fikri, hükmü yepyeni, yeniden ortaya koymak. Reformun manasında herhangi yeni bir şeyi ortaya koymak değil, yararlı, güzel iyi bir şeyi ortaya koymak şartı özünde bulunmaktadır. Bir daha reform kelimesini tanımlamadan, reform deyince bu anlamların bulunduğunu hatırlamak gerekir. Hz. Peygamber'in: 'İki günü eşit olan ziyandadır.' sözünü düşündüğümüzde, ikinci gün, birinciden gelecek gün geçmiş günden, bugün dünden artı bir şeyle farklı olmayı, fazladan, bir şey yapmayı ifade ederek geçmişle eşitliği bozmanın gerektiğini çok özlü bir ifade ile anlatmıştır. Bu sözün anlamı doğal kanunların nasıl değişikliğe neden olduğunu gösterir. Eskinin ve geçmişin değişmemesini kafalarına nakşedenler, dinin yaşanmasına ne kadar çelme taktıklarının mutlaka bilincinde ve bilgisinde olamazlar. Tarihte şunu görüyoruz ki bu gibi kimseler sözlerini sürdüre gelmişler ve günümüzde güya okur yazar olanlar da en iyi Müslüman olmayı, geçmişte, eskide aramayı ve onu olduğu gibi uygulamayı genç ve yaşlı zihinlere aşılamakta başarı göstermektedirler. Bu zihniyet teknik bilgilerle yıkılmıyor, daha güçlü bir biçimde sürüyor ve sürdürülüyor. 
Reform iki yöntemle, iki yoldan, yapılmalıdır. Reformun gerçekleşmesi için gereken bilgi kaynakları şunlardır:

\section{Ortam+Kur'ân (Akul+Vahiy)}

Dinde reform yapmanın temel kaynağı ortama göre Kur'ânı anlamadır. Eğer bir dinde reform yapılmak isteniyorsa o dinin belli, net bir kitabı varsa, kuşkusuz, önce o dini, kendi kitabı nasıl anlatıyor, onu iyice araştırıp tespit etmek en ilmî yöntemdir. Sonra onun üzerine bina edilecek reformların ne ve nasıl olması gerektiği ortaya konur. Íslâm dininin temel kaynağı Kur'ân'dır. Kur'ân, Hz. Muhammed zamanında yazılmış ve üzerinde, sözlerinde bir değişiklik olmayan tarihî bir vesikadır. İslâm dinini günümüz bilgisine, hayat şartlarına göre tarihsel anlayışın dışına çıkarak, onu aşarak, doğrudan Kur'ân'ı zamanımızda vahyolunmuş gibi anlayıp hayata uyarlamak ve yaşatmak için Kur'ân'ı anlamanın yöntemlerini, kurallarını, incelemek gerekmektedir.

a. Kur'ân'ın cümlesinin içinde bulunan kelimelerin etimolojik kök anlamlarını, Arapların o kelimeyi hangi anlamda kullandıklarını tespit etmek gerekir. Bunu tespit etmek için dördüncü hicrî (mîlâdî onuncu) asra kadar yazılmış olan sözlükleri taramalı, dördüncü asırdan sonra yazılan sözlüklere (lügatlere) çok ihtiyatlı bakmalı ve verdikleri manalan dördüncü asırdan önceki sözlüklerle karşılaştırmalı ve onlarda temel anlamlara dikkat etmelidir. Dördüncü asırdan sonra yazılan sözlükleri yazanın mezhebine delil olması için yanlış, kaygan eğilimli bir mana vermiş olabilir.

b. Kelimenin cümlede kullanıldığı biçimi, yani isim, sıfat olarak anlamını, kipini (sığasını) iyi anlamalı, aralarındaki farkı kavramalıdır.

c. Cümledeki fiil, sıfat ve isimlerin birbirlerine bağlanmalanın sağlayan edatların görev ve anlamlanna dikkat etmelidir.

d. Cümleyi cümle olarak, bir bütünlük içinde anlamaya çalışmalıdır.

e. Cümlenin benzerlerini Kur'ân'ın diğer âyetlerinde aramalı ve bulundukları yere göre yeni bağlamına (siyâk-sibâk) göre aralarında mana farklarının bulunup bulunmadığına göre karşılaştırarak anlamak gerekmektedir.

f. Cümlenin Kur'ân'ın bütünlüğü içinde anlamının ne olabileceğini düşünmeye gerek vardır.

Bu şekilde cümle tahlil edilerek anlaşıldığı zaman, bu anlayışla sözlük anlamında âyetin, cümlenin anlaşılması elde edilmiş olur.

\section{Kur'ân'ın İki Türlü Anlaşılması}

a. Kur'ân'ı Kerîm'in ilk planda basitçe anlaşılması, onu sözcüklerine göre anlamaktır. Burada sözcüklerin nasıl anlaşılacağını açıkladığımız gibi 
Benû Kurayza olayında da sözlük anlamının ne olduğunu belirttik. Bu sözlük anlamında, anlaşılmasında net, açık bir ifade ve deyim kullandık: 'Kur'ân ne dedi?' bunun hangi tür anlamda.. olduğunu, herkesin bu kadar anlayabileceğini, bunu anlamada çocuk, yaşlı, yetişkin, okumuş, okumamış, okumasını bilmeyen biri kendisine okunduğu zaman anlayabilir. $\mathrm{Bu}$ 'ne dedi?' anlayışında kalan bir kimse, yani Kur'ân'ı sözlïk anlamında kavramaya çalışan kişi, başkasına bir hüküm verme hakkına sahip olamaz. Ancak, kendisi Kur'ân'ın verdiği sözlü bilgiye sahip olur ve Kur'ân'ın felsefesi, hikmeti hakkında genel ilke ve hüküm anlatan kimsenin sözünü daha iyi kavramasına onu yükseltir. Bu sözlük anlamının hangi anlama geldiğini, ondan neyin amaçlandığını sorup öğrenme hakkına da sahip olur. Çünkü bir âyete dayanarak hüküm vermek yanlış olur. O hususta benzer veya onu açıklayan başka âyetleri ve o âyetleri birbirleriyle karşılaştırarak bir hükme varmak da yetmez, Kur'ân'ın genel felsefe ve ilkelerine göre de o âyetin anlamını düşünmek gerekir. Şunu da söylemek yerinde olur: Kur'ân'da şöyle diyor, demek suretiyle Kur'ân'ın ne dediğini hatırlar veya başkasına sadece hatırlatabilir. Ama Kur'ân'ın ne dediğine dayanarak bir hüküm veremez.

En az iki yüz yıldan beri İslâm dünyasında anarşi, karışı olaylar çıkaranlar; medreselerde okutulan dinî kültürden, bilimlerden nasibini almamıs, bir âyet ya da bir hadis veya bir fakihin sözünden cımbızla çıkarılmış bir sözü alıp bayrak yapanlardır. Eksikliği veya hiç bir kitâbî bilgiye sahip olmayanlar ayağa kalkıp dini tebliğ etmeye ve zorla dînî merasimleri, şekilsel giyim ve davranışları yaptırmaya kalkışanlardır. Bunlann içinde sosyal olayları, adaleti, haklılığı, dürüstlüğü, helalinden kazanıp helal yere harcamayı bayrak yapıp tavsiye eden yoktur. Bir âyetle, bir hadisle Müslümanlık olmaz, diyoruz. Eğer olsaydı, Kur'ân tek bir âyetten ibâret olurdu. Herkes kanunlardan herhangi bir maddeyi bilir. Şimdi bu kimse bir hukukçu, savcı, hâkim, avukat olabilir mi? İşte dini bilmek, Kur'ân'ı bilmek de böyledir. Herkesin haddini, neyi bildiğini, neleri bilmediğini bilmesi, Kur'ân'ın temel felsefesi ve insana en önemli öğüdüdür. Öyle ise Kur'ân' ın 'ne dediğini' bilmekte kalanlar, hadlerini bilmelidirler.

b. Kur'ân'ı Kerîm'in ikinci tür anlaşılması, sözlük anlamını aşıp 'ne dediğinden' hareket ederek 'ne demek istediğine' ulaşmaktır. Kur'ân bir sözü söylemekten neyi amaçlamış ve neyi hedefe almış, neyi anlatmak istemiştir. Kur'ân'ın ne dediğinden, ne demek istediğini anlamak; aklı kullanmak, Kur'ân'ın felsefesini, insana olan mesajını bilmek ve bir fikir, yeni bir anlam üretmek ve ortaya koymakla olur. Işte buna 'ictihâd' denir. Yukarıda Benû Kurayza olayında akılcıların, akıllarını kullanarak $\mathrm{Hz}$. Peygamber'in ne 
dediğinden ne demek istediğini çıkaranlanı, çabası, ictihada ve akıl yormalarına örnek vermiştik.

Şimdi burada Kur'ân'da hırsızlığa verilen cezayı hem ne dediğine, hem de ne demek istediğine ömek olarak incelemek yerinde olācaktır. Önce Kur'ân'da geçen âyetin Türkçe çevirisini verelim:

"Hırsızhk eden erkek ve hırsızlık eden kadının, yaptıklarına karşılık, Allah'dan caydırıcı bir ceza olacak biçimde her birinin ellerini kesin. Allah yücedir. Bilgedir. Kim yaptığı haksızlıktan sonra tövbe eder ve düzeltirse, kuşkusuz, Allah onun tövbesini kabul eder. Doğrusu Allah bağışlar ve acır." (Mâide, 5/38-39).

Âyette 's-r-k' kelimesinin türemişi olan 'sârik' (erkek), 'sârika' (kadın) kullanılmaktadır. Türkçemizde bunun mastarı veya mastar ismi olarak sirkat (asıl Arapçasında 'serik, serek, sereka, serika' olarak kullanılır: Çalmak, uğrulamak, aşırmak, hırsızlık etmek, hırsızlık yapmak; çalma, hırsızlık, sirkat. Türkçe sözlükte çalma; başkasının malını gizlice almak olarak tanımlanır; kendisine âit olmayan bir şeyi gizlice almak, hırsızlamak. Arapça sözlüklerde ise birisinin bir şeyini gizlice almak, gizli, saklı bir yerde olan şeyi almak olarak tanımlanır. Fıkıhta (İslâm Hukuku) hırsızlık: 'akıl-bâliğ, aklı başında yetişkin bir kimsenin başkasının belli değerde saklı bir malını veya onun değerinde bir şeyi gizlice almasıdır.'

Fıkhın bu tanımında hukukçular (fakihler) sözlük anlamına iki şart eklediler. Biri akıl-bâliğ, yani hem ergin, hem aklı başında olmak, diğeri çalınan malın belli bir miktar değeri olmak. Bunun anlamı şudur: Aklı başında olmayan ergin bir kimsenin ve henüz ergin olmayan çocuğun çalması, sirkate, hırsızlığa girmediği gibi, belirli (nisab) bir miktar ve kıymetten az olan bir şeyi de çalmak hırsızlığın tanımına eklenmekle, bu iki şartı eksik olan bir hırsızlığa âyetin hükmünün uygulanmasını kısıtlamak istemişlerdir.

İslâm hukukçuları (fakîhler) sirkat (hırsızlık) içine sokmak istemedikleri, ancak uzaktan ve yakından hırsızlıkla ilgili olan birkaç kelime veya kanuna yer vermektedirler. Bunları hırsızlık tanımının içine almamaktan amaçları; bunlara hırsızlığın cezasının dışında başka bir ceza verilmesini öngörmektir. Bu çabaları ve çalışmalarında hırsızlığın alanını daraltmak niyetinde oldukları anlaşılmaktadır.

\section{Bu kavramlar şunlardır}

1. İhtilas: Usulcacık, el çabukluğu ile aşırmak, özellikle para aşırma, hırsızlıkla aşırma arasındaki fark, hırsızlık gizliliğe, aşırma aleniyete ve hızlılı̆ga dayanır. 
2. Emânete hıyanet veya bilerek emaneti inkâr etmek.

3. Hirabe: Kuvvete dayanarak ortaya çıkıp mal almak; adam öldürmek veya terör, korkutma ve tedhiş hareketi yapmak.

4. Gasb: Sözlükte açıktan zulmederek bir şeyi almaktır. Terim olarak başkasının hakkına izni olmadan zorla sahip olmak.

5. Nebş: Bir şeyi yerden çıkarmak, açıp çıkarmak; ölünün kefenini soymak, nebbaş, kefen soyucu.

6. Neşl: Hızlı soyup almak, soyup çıkarmak, hızlıca kapmak, Buna tarr, yarmak, elleriyle kesmek, neş̧̧al, tarrar, insanlardan ustalık ve el çabukluğu ile uyanıklıklan sırasında bir şey çalma. Bunlara hırsızlık hükmünün uygulanmasında ihtilaf edilmiş ve ayrılığa düşülmüş olup fukahanın çoğunluğu bunun hırsızlıkla aynı olduğunu söylemiştir.

7. Nehb: Bir şeyi zorla almak, kapıp almak, talan etmek. Ancak hırsızlık sayılmamıştır.

$\mathrm{Ne}$ var ki, yeni yazılacak fıkıhta günümüzdeki yolsuzlukların, vurgunlann, suiistimallerin ve sâir suçların cezaları da yazılmalıdır. Eski fıkıh yeterli değildir.

Bunlarla burada yetinerek şunu vurgulamak istiyorum: Herhangi bir kimse bunları da hırsızlık kapsamı içine alarak hırsızlığa verilen hükmü bunlara da uygulayabilir. Peşinen şunu söylemek yerinde olur: Günümüz şartlarına göre hırsızlığı ve hırsızlıkla ilgili sözcükleri yeniden tanımlamak ve hükümlerini ona göre vermek, değiştirmek, geliştirmek gerekir.

Tekrar sirkate, hırsızlığa dönüp âyetin ne dediğini tespit ederek iyi anlamaya gerek bulunmaktadır. Hırsızlığın dört unsuru, öğesi vardır; onlardan biri olmazsa hırsızlık olayı oluşmaz.
A. Hırsız, hırsızlık eden (sârik-sârika).
B. Malı çalınan adam bilinmelidir.
C. Çalınan malın sahibi, malının korunması gereken birisi olmalıdır.
D. Gizlice almak.

\section{A. Hırsızın hırsızlıkla suçlanmasında beş şart vardır:}

1. Yükümlü mükellef olması gerekir; akıl-bâliğ olmalıdır.

2. Hırsızlığı kasten, bilerek yapmış olması gerekir; hırsızlığın haram olduğunu bilmemesi, elin kesilmesini önler. Çaldığı mala sahip olmak istemelidir.

3. Hırsızlık yapmaya zorlanmaması ve mecbur olmaması. Hırsızın ölümü kendinden savacak kadar çalması, elinin kesilmesini gerektirmez.

4. Hırsız ile malı çalınan kimse arasında akrabalık bağı olmamalıdır. Bunda genel kural, aralarında varis olma durumu olmamadır veya nikahı düşer durumu da olmamalıdır. 
5. Hırsızın çaldığı malda ortaklık şüphesi veya hisse sahibi olma durumu olmamalıdır.

$\mathrm{Bu}$ durumların ayrıntılarında fukahanın arasında değişik fikirler bulunmaktadır. Biz sadece temel ve ortak fikirlere işaret etmekle yetiniyoruz. Bunda amacımız, fukahanın hırsızlık olayına Kur'ân'ın verdiği hükmün; diğer bir deyimle Kur'ân'ın sözlük anlamına, ne dediğine göre fukahanın anladığı hükmün; yozların, cahillerin anladığı gibi, öyle kaptı-kaçtı, hemen yakalayıp el kesmek olmadığını vurgulamaktır. Fukahanın sözlerine dayanarak herkesin kolayca ve sükunetle düşünmesini sağlamakla onlara yardımcı olmaktan başka bir emelimiz yoktur.

B. a. Malı çalınan adam bilinmiş, tanınmış birisi olmalıdır. Çalınan malın sahibi, maliki bilinmezse, hırsızlık hükmü, Kur'ân'ın sözlük anlamındaki hükmü (el kesmek) uygulanmaz. Eğer çalınan malın sahibi bilinmezse, veya malın meşru sahibi ve koruyucusu değilse, hırsızlık hükmünün uygulanıp uygulanmayacağında fukaha değişik görü̧ş ortaya koymuşlardır.

b. Malı çalınan kimsenin malının güven altında, korunması gereken birinin malı olmalıdır; bu durumda-çalma, hırsızlık hükmü (Kur'ân'ın sözlük anlamına göre hükmü) uygulanır. Müslüman ve zimmî (Islâm toplumunda yaşayan, vatandaş olan gayr-i müslim) olanın malları güven ve korunma altında olduğunda, fukaha arasında ittifak hasıl olmuştur, hepsi aynı görüştedir. Ancak müste'men (emân verilen, güven verilen), pasaportlu olan yabancı bir kimsenin malı çalındığında, çalana hırsızlık hükmünün uygulanmasında fukaha aynı görüşte değildir. Mâlikîler, Hanbelîler ve Hanefîlerden İmâm-ı Züfer, pasaportlu kimsenin malının da güven altında olduğu görüşünde olarak, çalana hırsızlık hükmü uygulanır, demiştir. Ancak burada şunu hatırlatmakta fayda vardır: El kesme (hırsızlık) hükmü uygulanmazsa, cezasız birakılmaz.

C. Çalınan mal: Çalınan mala hırsızlık hükmünün uygulanması için üç şart bulunması gerekli görülmektedir: a) Mütekavvim; b) Nisâb (belirli bir miktar) olmalı. c) Saklı olmalıdır.

a-1) Çalınan nesne değer biçilebilen, kıymetli olmalıdır. Çalınan nesne mal olmalı, mal olarak sahip ve malik olunacak nesne olmaktan maksat, hür bir insan gibi, mal olmayan bir nesne olmamalıdır. Hür bir insanı (büyük, küçük olsun) çalana hırsızlık hükmü uygulanmaz.

2. Çalınan malın bir değeri, kıymeti olmalıdır. İslâm dînine göre mâlî kıymeti olmayan domuz, içki çalma gibi durumlarda hırsızlık hükmü 
uygulanmaz. Çalınan malın mütekavvim olmasının tayininde fukaha farklı görüştedirler. Ara sıra söylediğimiz gibi, hiç cezasız kalması değil, Kur'ân'daki sözlük anlamından anlaşılan el kesme hükmünün kalkması amaçlanmaktadır.

3. Malın sahiplenilmiş bir nesne, mal kabul edilip saklanması mümkün olan, fıkıh deyimiyle mütemevvel olan bir nesne olması gerekir. Bunda da ayn görüşler bulunmaktadır.

b. Nisâb, çalınan malın belirli bir miktar veya belirli bir kıymette olması şartır. Bazı hadislere dayanarak çalınan malın bir dinar (alıın para) veya on dirhem (gümüş para) değerinde olması zikredilmekle birlikte fukahanın farklı görüşleri bulunmaktadır. Yalnız şuna dikkat edilmesi gerekir: $\mathrm{Hz}$. Peygamber'in döneminde bir dinar altın paranın alım değerinin göz önünde bulundurulması gerektiğini söylemekten kastım, bugün bir altın liranın (dinarın) alım değeri daha düşük olabilir. Mesela Amerika'da bir dolarla belki bir elma alınıyorsa, Rusya'da ve diğer memleketlerde bir dolarla daha çok şey alınabilir. Her paranın alım değeri yere ve zamana göre değişir. Altmış sene önce beş kuruşla ekmek ve helva ile kann doyuruyorduk.

Bu nisâb konusunda da zaman, mekan ve değer bakımından ayrı görüşler ileri süren fukaha durumu yüksek ve sert tutanlar hırsızlık hükmünün uygulanmasının alanını ve sınırını daraltmak istemektedirler. Her zaman bu konuda böyle ayrı sert veya yumuşak, gevşek görüş ileri sürmelerinin anlamı, böyle görüş ve fikir üretmeleri; fukahanın, uzmanların, düşün sahibi kimselerin meşru hakları olduğunun ortaya konmasının gereği olmasıdır. Bu hususa önem vermek ve ona göre davranmak, söz söylemek, tartışmak meşru bir durumdur.

c. Çalınan malın saklanılan bir yerden alınmış olmasıdır; çünkü saklı bir yerde olmayan mal sanki sahibi tarafından önemsenmemiş, yitirilmesine sebep bir olaya göz yumulmuş olur. Kimi fakihler, malın saklı yerden alınmasının Kur'an'da olmadığını ileri sürerek bu şartın geçersiz olmasını söylemişlerdir. Doğrusu, yukarıda sayılan diğer şartlar da Kur'ân'da olmadığı halde onlara itiraz edilmemiştir. Görüş ayrılıkları, şartların varlığına değil, şartların niteliklerinde ve gerçekleşme derecelerinde ortaya konmuştur. Saklı yerin ne olduğunda da ittifak edilen ve ayrışılan görüşler olmakla beraber en çok itiraz edilen yerlerden bazıları şunlardır: Bunda genel kural şudur: İzinle girilen her yer, dükkan, ev, çadır gibi. Mesela izinle eve giren misafir, evin hizmetçisi, evden bir şey çalarlarsa, bunlara hırsızlık cezası değil, hâinlik cezası verilir. Mescit gibi herkesin girip çıktı̆̆ı yerde bekçi yoksa, çalınan halı, kilim, kandil, Kur’ân vb. hırsızlığa girmez. Ancak 
bekçisi olursa, hırsızlık hükmüne girer. Bunda da bazı ayrıntılarda fakihlerin farkh görüşleri bulunmaktadır.

Ben, Kur'ân'daki ayetin uygulanması konusunda fukahanın ortaya koydukları görüşlerin değişikliklerine ışık tutacak bir fikir vermek suretiyle, öyle kanun tanımaz, kanunun ne demek olduğunu bilmez, anlamaz kimselerin hukukla ilgili âyetleri tarihte fukahanın nasıl anlamaya çalıştığını kısaca örnekleyerek, günümüzde de günümüz şartlarına ve kültürüne göre uygun bir ilmî çalışmanın ve fikir, görüş ortaya koymanın gereğini vurgulamak istiyorum.

\section{Gizli Almak.}

Hırsızhık işinin tam oluşması için bu dördüncü öğe, unsur, bir nesneyi gizli bir yerden alıp çıkarmak şarttır. Dışarı çıkarma tamamlanmamış ise, buna hırsızlık hükmü değil, başka bir ceza verilir.

Hz. Ali'den şöyle bir söz nakledilir: 'Hırsız zarif ise eli kesilmez.' Bu ne demektir, diye sorulan soruya, şu cevabı vermişti: 'Duvarı deler, kendisi girmeden, elini sokar malı çıkarır.'

Ebû Yusuf (Hanefî), Mâlikîler, Şafîiler, Hanbelîler hırsızın saklı yere girmesinin şart olmadığını, önemli olan saklı yerden malın alınmasıdır, demişlerdir.

Fukaha ince eleyip sık dokumak suretiyle hırsızlık hükmünün uygulanışını kısıtlamakta ve zora sokmaktadır. Tam bir hukukçu inceliği ile ayrıntılara inmektedirler. Çalınan malın saklı, gizli, yerden sahibinin mülkiyetinden, elinden çıkıp hırsızın mülkiyetine girmeyi de şart koşmanın anlamı; çalınan mal hırsızın mülkiyetine, sahipliğine girmemiş ise, yani hırsızın eline geçmemiş ise, çalana hırsızlık hükmü uygulanmaz demektir. Fakihler arasında hırsızlığın tam oluşup oluşmadığının, hangi durumlarda ve nasıl oluşabileceğinin tespiti hususunda değişik ve ayrıntılı görüşler ileri sürülmüştür.

Ancak şu kuralda çoğunluk ittifak halindedir: Hırsızlık tam oluşmamış ise, hırsızlık hükmü uygulanmaz. Ancak $t a$ 'zir cezası verilir. ${ }^{1}$

\section{Hırsızlığın İspatı:}

Hırsızlığın ispatı hususunda ittifak edilen ve ihtilafa düşülen deliller bulunmaktadır. Bunlar dört tane olarak anlatılmaktadır:

1. İtiraf: Hırsızlığın itiraf etmekle sabit olacağı konusunda ittifak edilmiştir. Hırsızın itiraf etmesinin ilk şartı akıl-bâliğ, yani mükellef, dinen

1. Ta'zîr: Kur'ân'da tayin edilmeyen ve hâkimin takdirine bırakılan cezâ. 
sorumlu ve yükümlü olmalıdır. Fakihlerin çoğunluğunun ileri sürdüğü şart, itiraf etmesinde hür, serbest olmalıdır. Hapsetmek, dövmek gibi zorlayarak yaptırılan itiraf meşru sayılmamaktadır. Ayrıca hırsızlık hükmünün verilmesine dayanak ve delil olacak itiraf, açık seçik olmalı ve hakimin (kadı) şüpheye yer bırakmayacak biçimde hırsızlığın oluşması gereken öğelerin bulunduğundan emin olması gerekir. Sonra itiraf, hırsızlık hükmünü uygulayacak zatın huzurunda olmalıdır. Başka yerlerde itiraflar muteber sayılmamaktadır. Bununla beraber çalınan malı dava eden bulunmayınca, itiraf kabul edilmemektedir. Kimi fukaha bu şartın Kur'ân'da olmamasından dolayı, böyle bir şartı doğru bulmayıp hırsızlık hükmünün uygulanmasının gerektiğini söylemişlerdir.

2. Beyyine: Apaçık delilin bulunması ile hırsızlık sabit olur. Buna göre hırsızlık, tanıklık (şahitlik) etme niteliklerini haiz iki erkek şahidin tanıklığı gerekmektedir. Bu nitelikler; erkek, müslüman akıl-bâliğ, hür, gözleri gören âdil ve hür iradeli olmaktır.

3. Tekrarlanmış yemin²; yemin-i mardude ile Hanefî, Mâlikî ve Hanbelî fakihlerinin çoğunluğuna göre hırsızlık sabit olur. Ancak hırsızlık hükmü sabit olmaz. Bu yeminle malın çalındığı sabit olur. El kesmek ancak, itiraf ve delil ile olur. Reddedilen yemin şudur: Davacı, davalının elinin kesilmesini gerektirecek bir hırsızlık yaptığını iddia eder ve davalı hırsızlığı inkar edince, hırsızlık yapmadığına yemin etmesi istenir. Ancak yemin de etmezse; bu durumda yemin davacıya teklif edilir. Davacı, davalının hırsızlık ettiğine yemin ederse, davacının yemini ile hırsızlık sabit olur. Fakat el kesme cezası verilmez. Şafî̀lere göre bu yeminle hırsızlık hükmü uygulanır.

4. Karine ile, yani ilişkili, ilgili bir belirti delil ile de hırsızlık hükmü sabit olur, uygulanır. Kimileri böyle bir delil ve karine ile de hırsızlık hükmünün sabit olmasını doğru bulmuş ve İbn Kayyim, örnek olarak çalınan malın suçlananın yanında bulunmasını zikretmiştir.

\section{Hırsızlığın Cezası:}

Hırsızlığın cezası, hırsızın elini kesmek olduğunda fukaha görüş birliği içindedir.

Kesilecek yer: Fukahanın çoğunluğu bilekten kesilmesini önerirken kimileri de omuzdan kesilmesini ileri sürmüştür.

Hırsızlık tekrarlandığında fukaha arasında şu görüşler ortaya atılmıştır:

a. Hüküm giymeden önce birkaç kere hırsızlık yapana tek bir ceza verilir ve bir eli kesilir; çünkü şüphe vuku bulursa el kesme cezası düşer.

2. Nihâyet'ül-Muhtâc, c. VII, s. 431 . 
Burada asıl maksat hırsızlığı önlemektir. Bu da bir defa ceza vermekle sağlanabilir.

b. Hüküm giyip eli kesildikten sonra tekrar hırsızlık ettiğinde kimilerine göre ikinci eli de kesilir. Kimilerine göre ikinci eli yerine, sol ayağı kesilir; vardır.

c. Üçüncü kez hırsızlık ederse, sol ayağı kesileceğini söyleyen fakihler

d. Üçüncï kez hırsızlık ettiğinde sol ayağı kesilmez, çünkü Kur'ân'da ayak sözü geçmemektedir. Bu, Kur'ân'a ilâve edilmiş olur ve câiz olmaz. Başka ceza verilir.

e. İkinci kez hırsızlık ederse, kimilerine göre sol ayağı ve üçüncü kez hırsızlık ederse sol eli kesilir. ${ }^{3}$ vardir. ${ }^{4}$

f. Dördüncü kez hırsızlık ederse, sağ ayağı kesilir, görüşünde olanlar

g. Beşinci kez hırsızlık ederse, kimilerine göre öldürülür.

Kesme ile ilgili bütün görüşleri burada özetlemekten maksat, fâkihlerin içinde ne kadar saçmalıkların bulunduğunu ortaya koymaktır; hepsini ayrı ayrı tenkit etmenin yerine şu beşinci kez hırsızlığın nasıl vuku bulacağımı hayal etmek bile imkansızdır. Adamın iki eli kesilmiş, iki ayağı kesilmiş, nasıl yaşayacağını düşünme yerine, bu durumda ağzı ile mi, başı ile mi gidip hırsızlık edecek? Burada en akıllı hüküm, eğer kesilecekse, bir eli kesilir, ondan sonra başka ceza verilir, diyenlerinin görüşü olmalıdır. Bu görüşün dışında olanlar, dinin insan için olduğunu değil, insanın din için olduğunu kabul eden ve uygulayanlardır. Bunlar Kur'ân'ın felsefesini, amacını anlamaktan uzak düşmüşlerdir.

\section{El Kesme Cezasının Düşmesi:} duişer:

Hırsılık sabit olduktan sonra el kesme cezâsı şu durumlarda

1. Hırsızlık edene aracılık edip elinin kesilmesini önlemek imkânı bir şarta bağlanmıştır. Hırsızın hâkime şikayet edilmesinden önce, yani hâkime gitmeden araya girip hırsızlık hükmünün verilmesini engellemek caizdir.

3. Hz. Ali'den gelen bir söze göre demiştir ki: 'Hırsızın birinci hırsızlığında sağ eli, ikinci hırsızlığında sol ayağı kesilir. Üçǘncü hırsızlığında ise hiç bir yeri kesilmez, başka cezâ verilir; meselâ hapsedilir. Hırsızı yemek yiyecek ve ihtiyacını görecek elsiz ve yürüyeceği ayaksız bırakmaktan dolayı Allah'dan utanırım.' Hz. Ali bu görüşünü hırsızın sağ eli ve sol ayağına da teşmil etse ne olurdu? Demek ki, Hz. Ali bile o zamanın zihniyetinin ve anlayışının etkisinde kalmıştır.

4. 'Elin veya ayağın, sürçmene sebep oluyorsa, onu kes ve kendinden at; sana çolak veya topal olarak hayata girmek, iki el veya iki ayağın olarak ebedî ateşe atılmaktan daha iyidir' (Matta, 18/8). 
Ancak hakime şikayet edilince, artık iş hâkimin hükmetmesine ve hırsızlık hükmünü uygulamasına kimse engel olmamalıdır.

2. Hırsızın malı çalınan tarafından af edilmesi ile de hırsızlık hükmü yani el kesme hükmü düşer. Bunda da şart hâkime bildirilmemiş olmalıdır.

Âyete baktığımız zaman âyetin sözlük anlamı içinde böyle bir şartı anlamak için bir belirti bulunmamaktadır. Bu iki madde, hırsızlığın mutlaka eli kesmenin yani şartsız eli kesmenin olamamasının caiz ve doğru olduğunu ifade ediyor. Bunu ileride âyetten kastedilen anlamın ne olduğunu ve ne demek istediğini anlatırken ele alacă̆ız.

3. Fukaha samimi tövbenin hırsızdan ahiret azabını kaldıracağında ittifak etmişlerdir. Ancak dünyada elinin kesilmesi konusunda fukaha ikiye ayrılmıştır:

a. Hırsızın elinin mutlak kesilmesini öngörüyor; çünkü âyette tövbe eden ile tövbe etmeyen ayrımı yoktur. Hz. Peygambere tövbe eden bir hırsızı getirmişler, Peygamber hırsızlık hükmünü uygulamış, diyorlar. Burada kaçırdıkları bir husus vardır. Buranın (1-2) maddelerinde geçen hâkime şikayet edilince, hâkim hükmü mutlaka uygular. Hz. Peygamber hâkim (kadı) durumunda olduğundan yapılan şikayeti göz ardı edememişti. Bu noktayı kaçırdılar.

b. İkinci âyet birinci âyete atfediliyor. Onun anlamına ek ve açıklama yaptığına dayanan fakihler, tövbe edenin hırsızlık hükmü cezasının düşeceğini söylemişlerdir. Yoksa, hırsızlık hükmünün uygulanışından sonra tövbe etmenin âyette geçmesinin bir anlamı olmaz.

4. Eğer hırsız hırsızlığını itiraf etmekten vazgeçer, dönerse hırsızlık etmesi şüpheye düşeceği için ona hırsızlık hükmü uygulanmaz.

5. Hırsızlık hükmü giymeyecek kimse ile ortakçılığı varsa; çocuk ve deli olanlarla ortak olarak hırsızlık yapmışsa, çocuğa ve deliye hırsızlık hükmü uygulanamayacağı için, hepsi de aynı hırsızlıkta ortak olduklarından hiçbirisine hırsızlık hükmü uygulanmaz. Kimi fakihler, hırsızlık hükmü uygulanabilecek şartı haiz olanlara hüküm uygulanır, demişlerdir.

6. Eğer çalınan malı hırsız satın almak, ya kendisine hîbe edilmek gibi durumda sahip olursa, hırsızlık hükmü düşer. Bazı fakihler durumu ayrıntılayarak, hükmün uygulanmasını gerekli görmüşlerdir.

7. Hırsızlığın üzerinden uzun zaman geçmişse, kimilerine göre hırsızlık hükmü düşer, kimilerine göre düşmez.

8. Herhangi bir hırsızlığın tam oluşması için şartlar ve unsurlar oluşmamış ise, hırsızlık hükmü (el kesme) düşer ve ta'zir cezası verilir.

9. Çalınan malı ödeme konusunda fukaha üçe ayrılmıştır: 
a. Çalınan mal mutlaka ödenmelidir. Hırsız zengin de olsa, fakir de olsa, eli kesilse de kesilmese de çaldığını ödemek zorundadır. Bunlara göre bir suça iki ceza vermek caizdir ve gereklidir. Bir ceza kişinin hakkı, öbürü Allah'ın (kamûnun) hakkıdır.

b. Çalınan mal -yok olmuş, telef olmuş olsa bile- hırsız zengin ise hüküm giyene kadar (el kesme vaktine kadar) malı öder. Çünkü hırsızın zengin olması durumunda, çalınan mal aynen mevcutmuş gibi kabul edilir. $\mathrm{Bu}$ durumda iki ceza birleşmez. Hem ödeme, hem de el kesme cezası verilmez. Ödemeyi önceden yapmışsa, el kesilme cezası kalkar.

c. El kesilince hiçbir surette çalınan mal ödenmez. Çünkü Kur'ân'da el kesme cezası var, ödeme cezası yoktur. Eğer ödeme cezası da verilecek olursa, o zaman, el kesme cezasının yeterli olmadığ ve ceza tam sayılamayacağı ortaya çıkar. Kur'ân el kesmeyi, cezanın tümü olarak ifade etmiştir. Bundan dolayı iki ceza birlikte verilemez, demişlerdir. Eğer hırsız ödeme yapmışsa, artık çaldığı mal kendi malı olmuştur. Bu durumda ona hırsızlık hükmü (el kesme) uygulanmaz. Zira bir kimse kendi malından dolayı elinin kesilmesi hükmüne uğratılamaz.

Buraya kadar iki âyetin sözlük anlamını, yani ayetlerin ne dediğini inceleyen fakihlerin görüşlerini ve sözlüklerden ne anladıklarını gözden - geçirmiş olduk ve şunu gördük: Fakihlerin hepsi âyetin kullandığı (kat') (kesmek) kelimesini fizikî anlamda ipi kesmek, ağacı kesmek, ekmeği kesmek, hayvanı kesmek anlamında olarak esas almış ve yorumlannı, görüşlerini buna dayandırmışlardır. Ancak el kesmenin, öyle basit, bayă̆ı adi bir olay olmadığının bilincinde olarak bunun önüne geçmek, bunu engellemek konusunda oldukça akıllarını kullanmış, sözlüklere başka anlamlar eklemiş, el kesmenin alanını kısıtlamaya çalışmış ve bunları yapmak için sözlüklerin dışına taşmak zorunda kalmışlardır. Sözlüklere yeni anlamlar eklemeyi yerenler de olmuştur. Öyle anlaşılıyor ki, hırsızın elinin kesilmesi İncîl'de de (4) bulunduğuna göre, el kesmeyi Kur'ân ilk defa ortaya koymuş olmuyor. Hırsızın elinin kesilmesi yaygın, zihinlerde yeri var. İşte yukarıda Hz. Ali'nin de bunun etkisinde olarak Kur'ân'ın sözlük anlamından uzak kalmadığını söylemiştik. Hz. Ali'nin görüşü tıpatıp İncil'deki hükme uymaktadır. Ancak yinelemek gerekir ki, hırsızın elinin kesilmesini temel alan fakihlerin bir kısmı, daha makbul ve anlamlı bir görüş ileri sürerek, yalnız tek elin kesilmesinin yeterli olacă̆ını ve tekrar hırsızlık olaylarında ta'zir cezası verileceğini öngörmüşlerdir.

Şimdi biz âyetleri, Kur'ân'ın veya herhangi bir metnin ve sözün 'ne demek istediğine', amacına, hedefine göre anlamak üzerinde duracağız. 
Yineleyelim ki, âyetin 'ne dediğine' göre anlaşılması sözlük, lafız, kelime olarak anlaşılmasıdır.

Asıl anlam, âyetin ne demek istediğine ve neyi anlatmak istediğine göre anlaşılması, Kur'ân'ı geleceğe yönelik anlamak olduğu için çok önemlidir. $\mathrm{Bu}$ tür anlayışla, Kur'ân'ı her yerde, her zaman, her toplumda ve bir toplumun değişik, gelişen dönemlerine göre uygulama, yaşama imkanı ortaya çıkar ve insanlar hem imanl, hem dindar, hem mutlu olurlar, hem de hayatın her zorluğunu kolaylıkla yener ve rahat ederler.

\section{İslâm'ın Kolaylaştırma İlkesine Karşı Çıkan Fıkıhçıların Zorlaştırmalarına Bir Örnek}

On bir asırdan beri fakihlerin çoğunluğunun (cumhur-fukaha) önem vermedikleri, göz ardı ettikleri, en doğru tespitte tersine, zıddına hüküm verdikleri, Müslümanlara dinde kolaylığı anlatmayıp sürekli zorluğa sürükledikleri gerçeğidir. ${ }^{5}$

Dinde kolaylık, Kur'ân' In ve hadislerin üzerinde titizlikle durdukları Islâm dininin en temel ilkesidir. Temel ilkenin anlamı, bütün hükümlerin ve uygulamaların buna göre ayarlanması zorunluluğu vardır. En basit örneklerden bir tanesini yukarıda anlattım. Burada şu örneği vereyim: Hz. Peygamber sahur yemeğinin, sabahleyin güneş doğumundan önce beyazlığın, aydınlığın ufukta sağlı, sollu yayılmasına kadar, yenilebileceğini söylemiştir. Fakihler burada üçe ayrıldılar:

a. Mutlaka aydınlı̆̆ın yayılmaya başlamasına kadar sahur yenir demişti.

b. Aydınlık tam yayılana kadar yenir, demişti.

c. Aydınlığın son bulmasına kadar, demişti.

Islâm'n temel felsefesini anlamamış güya bir fakih şöyle diyor: 'Bunların içinde, a) bendine, yani aydınlığın başlamasına göre, sahuru bitirmek daya iyi olur, ihtiyatlı olur.'6 Iş̧e dini zorlaştırmak, burada oldukça iyi görülüyor. Her türlü hükümde dini zorlaştırmak budur; ihtiyatlıdır, daha iyidir, dedikleri dinin en zorla yapilan hükmüdür. Bu gibi hükümlere, fetvalara bakarak dini kendisine zorlaştıran kimse, kendisine zulmettiği için daha çok sevap kazanacağını sanarak kuşkusuz günah kazanıyor. Çünkü dinin o kadar zorla yapılabileceğini gören kimse, dinden soğuyabilir ve bu yüzden daha çok ihmâle sürüiklenir. Bundan dolayı günâhı öyle yapmasına sebep olana da gider.

5. Bkz. Kur'ân'a Göre Araştırmalar, c. I ve c. III adlı eserimiz. 'Dinde Kolaylık Meselesi' burada uzunca anlatılmıştır.

6. Kur'ân'a Göre Araşturmalar, c. IV, Sahur Bahsi. 
Oysa Hz. Peygamber'in sünneti; iki şeyden birini yapmakta serbest olursa, en kolayını yapmayı tercih ederdi ki, Müslümanlar da ona uysun ve dini kolaylaştırsınlar.

Kur'ân'ı Kerîm'de yüce Allah insanlara şöyle duada bulunmalanıı emir veriyor:

"Rabbimiz, bizden öncekilere yüklediğin gibi bize de ağır hüküm yükleme! Gücümüzün yetmeyeceğine bizi zorlama! Bizi affet!" (Bakara, 2/286).

"Peygamber, onlara ağır gelen yükümlülüikleri ve bukağlları kaldırır." (A'râf, 7/157).

$\mathrm{Bu}$ âyetler gösteriyor ki, önceki ümmetlere daha ağır hükümler yüklenmiş ve Kur'ân'da onlar kaldırılmıştır. Incîl'de olan el kesmek bunlardan birisi olmalıdır örneğin.

\section{El Kesmede Denilen ve Denilmek İstenen}

Burada üç kelime âyetin anlamına veya ne demek istediğine yön vermekte ve ışık tutmaktadır. Biri (kat') kelimesi. Bu kelime günlük konuşmada iki anlamda kullanılmaktadır:

Birincisi, bir şeyi kesip ayırmak, maddî şeylerin kesilmesinde kullanıldığı gibi Türkçe'de benzeri kesmek aynı anlamı verir.

Diğeri, iki şey arasındaki ilişkiyi kesmek, engellemek. Arapça'da kataa lisânehû: Dilini kesti, demek, onu susturdu, konuşmasını kesti, anlamında konuşmasını engelledi, demek olduğu gibi Türkçe'de de elini kesmek, men etmek, engellemek anlamında kullanılmaktadır. Arapça'da 'Kata'as-sadîka' arkadaşını kesti anlamında olmayıp, arkadaşını terketti, bıraktı, arkadaşı ile ilişiğini kesti, demektir. 'Kata'as-sıla' ilişiği kesti, bu anlam Kur'ân'da da kullanılıyor; 've yakta'ûne mâ emere allahu bihi en yûsale' (Allah'ın birleştirilmesini buyurduğu şeyi ayınrlar' (Bakara, 2/27). Burada akrabalık ilişkisini keserler, akrabalık bağlarını ayırırlar, demektir Arapça'da 'kata'a en-nehre' nehri kesti anlamında değil, nehri karşıya geçti, demektir.

'Kata'a rahimehû' rahmini, döl yatağını kesti anlamına değil, akraba ilişkilerini kesti, demektir. 'Kata'a unuka dabbetihi' hayvanın boynunu kesti değil, hayvanını sattı, demektir. 'Kata'a; haceze, menetti, 'avkafa' durdurdu, demektir. Türkçe'de 'ayağını kesmek' fizikî ayağını kesip bedenden ayırmak olmayıp 'bir yere gitmemek, bir yere gitmesini engellemek, demektir.

Burada şunu vurgulamak yerindedir: Kesmek anlamında âyette kullanılan 'fakta' $\hat{u}$ ' kelimesinin lügatteki anlamı iki manaya geliyor: Maddî bir şeyi kesip ayırmak, ve iki nesne arasındaki ilişkiyi, bağlantıyı 
engellemek, men etmektir. Bu iki anlam da sözkonusu kelimenin sözlük anlamıdır. Ancak Hz. Peygamber zamanından bu yana hep maddî eli kesip bedenden ayırmak olarak anlamışlar. Böyle anlaşılmasında İncil'in etkisi olabilir, diyoruz. Ancak Kur'ân'ın insana vermiş olduğu büyük değere bakarak, gene sözlük anlamı olan ilişiği kesmek, engellemek anlamını niçin vermediklerini anlamak zor olmaktadır. Oysa burada açıklandığı gibi 'kataa' kelimesinin sözlük anlamından bile hırsızlığı önlemek anlamının uygulanmasına gitmek de mümkün idi. Demek ki, toplumun etkili zihniyeti insana yön verebiliyor.

Burada Kur'ân' in 'ne demek istediğine' tekrar gelmek istiyorum: Âyetin amacı, felsefesi hırsızlığı önlemek, engellemek olduğunu anlamak daha kolay ve Kur'ân'a uygun düşer. Adamın eli kesildiği zaman başkasına daha çok muhtaç biri durumuna getirilmiş olur. Bu nedenle ayrıca ona bakmak gerekecektir. Âyetin demek istediğini anlamak, hırsızlığı önlemek olunca, bu önlemeyi hâkim yapacak ve hırsıza nasıl caydırıcı bir ceza vereceğini kendisi düşünecek ve bu ceza kişiye, zamana, mekana göre değişecek bir ceza olacaktır. Birine bir zamanda ve mekanda verilen ceza her zaman, her yerde ve herkese verilen dondurulmuş bir ceza olması yanlış, etkisiz veya haksız olabilir. Yukarıdaki fakihlerin görüşlerine dikkat edilecek olursa, el kesmeye hüküm vermekte zorlandıklan zaman, bu sert hükmü vermeyi uygun görmedikleri zaman, el kesmekten vazgeçip ta'zir cezasına gitmektedirler. Biz böyle bir sıkıntı olmadan doğrudan ta'zir cezasına gidilmesini, âyetin ne demek istediğine ve Kur'ân'ın felsefesine ve amacına daha uygun buluyoruz.

Biz de Kur’ân çevirimizde: ‘ellerini kesin’ kelimesini kullandık. Ancak burada elleri kesmek, fizikî anlamda anlaşıla geldiği gibi, kesmek anlaşılmašı hemen insanın aklına geliyor. Fakat el kesmek, engellemek, men etmek, anlamına da geldiği için 'ellerini engelleyin, hırsızlık etmelerini önleyin.' anlamına gelmektedir. Bu anlam âyetin amacına ve felsefesine uygun olduğu için, âyetin çevirisini: 'Hursızlık eden erkek ve hirsizlık eden kadına engel olun; hirsızlik eden erkeğin ve hırsız kadının hirsızlıklarını önleyin.' biçiminde yapmak yanlış olmaz. Daha önceleri şöyle bir görüşümü de burada yinelemek istiyorum: El kesmek amaç ve hedef olmamak şartıyla, hırsızlı̆̆ı önleme yetkisi hâkime bırakılmalı; hâkim herhangi bir ceza ile hırsızlığı önlemeye çalışır; bütün yolları denediği hâlde hırsızlığı önleyemiyorsa, ancak el kesmek sûretiyle önleyebileceğine dâir kesin bir kana'ate ulaşmışsa, hâkimin bu kanâ'atine göre hüküm vermesine de imkân tanınabilir. Savaşta hırsızlık edenin elinin kesilmemesindeki nedenlerden biri de savaşta onun eline ihtiyaç duyulmasından dolayıdır. Eli kesilirse ona 
hizmet edecek birine ihtiyaç olduğu hâlde, eli kesilmezse, başkasının ihtiyacına yardımcı olacaktır.

Âyette geçen 'nekâl' kelimesi, men etme, engelleme, caydırma anlamına gelmektedir. Hırsıza verilecek cezanın caydırıcı olması niteliği de vardır. Ceza caydırıcı olacak diye, işi zulme götürme hakkı yoktur. Birçok âyette 'size yapılan kötülük kadar, kötülük yapın.' (Bakara, 2/194, 190; şûra, $42 / 40,6 / 60 ; 10 / 27$ ), ilkesi Kur'ân'ın temel ilkelerinden birisidir. Burada caydırıcı olmak, iki şekilde olur: Başkası o cezayı görürse, kendisi öyle bir suç, günah işlemeye yiğitlenemez. Hırsızın kendisi de bir daha hırsızlık yapmayı yüklenemeyecek bir ceza yer, bir daha o sıkıntıya katlanamaz. Bu, hırsızın elini kesmede olmaz. Çünkü artık hırsızlık yapma yeteneği kırılmış ve eksiltilmiştir. Mutlaka elini kesmeden verilecek bir ceza da caydırıcı bir ceza olabilir. Bunun için caydırıcı cezanın içine sırf el kesmeyi koymak yanlış olur.

Hırsızlıkla ilgili âyetin hemen peşinden, arada bir hüküm, olay olmadan gelen âyette Cenâb-ı Hak diyor ki: "Bu zulümden (hırsızlığından) sonra hemen tövbe ederse ve düzeltirse, Allah onun tövbesini kabul eder.' (Mâide, 5/39).

Bazı fakîhlerin bu âyete dayanarak hırsızlıktan sonra hemen tövbe ederse, hırsızlık hükmünü yemez, görüşleri yerindedir. Elinin kesilmesinden sonra tövbe etmesinin bir anlamı kalmaz. Tövbe etmekle hırsızlık hükmünü yemenin anlamı, eli kesilmez, ancak çaldığı kendisine ödetilir. Tövbe etmeyi, âhiretteki günahının affa uğramasına yoranların, dünyada bir etkisi olmaz. Aslında suçlunun tövbe etmesinin, dünyadaki işten vazgeçmesini sağlamak için hem sosyal, hem psikolojik yararı vardır. Hem bir daha hrrsılık etmeyecek, hem eli kesilmeyecek, hem de âhirette günahı affa uğrayacaktır. Bazı kimseler tövbeyi önemsiz görüyorlar. Oysa ben tövbeyi Kur'ân'ın en çok önemsediği anlamda algılıyorum ve tövbe en büyük cezâdır, diyorum. Çünkü tövbe, en büyük günâh olan şirki, Allah'a ortak koşmayı silip süpürüyor ve kaldırıyor. Doğrusu tövbenin insanın haklarına şâmil olması, telâfi edilecek suçlardadır. Tövbe, yapılan bir işin yanıı̧̧ığını kabul edip yapılan zararın ödenmesini de aynı zamanda içerir. Bu zararı ödeme gerekir. Ancak yapılan zararı telafi edip ödeme imkânı yoksa, borçlandırılır veya çalıştırılır; ancak tövbe Allah katında, âhirette o cezasını affettirir.

$\mathrm{Bu}$ âyeti kerîmenin üzerine çok itirazlar olduğu için, ben de bunun tarih boyunca nasıl anlaşıldığı üzerinde durdum. Gördük ki, fakihler âyetin sözlük anlamlarında fizikî kesmeyi temel anlam alarak, birçok değişik görüşler ve ictihâdlar ortaya koymuşlardır. Bunların içinde âyetin 'ne demek istediğini' 
hesaba katmadan, onu açıkça ifâde etmeden 'ne demek istediğine' ve bize göre amacına uygun düşecek görüşler ortaya koyanlar da olmuştur.

İşte biz de âyeti 'ne demek istediğine, neyi anlatmak istediğine' göre anlamaya ve açıklamaya çalıştık. Âyetten maksadın hırsızlığı önlemek olduğu sonucuna vardık. Bu âyeti bu şekilde anlama da neticede bir yenilik ve reform sayılır. Kur'ân'ın her âyetine göre iki türlü anlayışın tarihte müctehidler tarafından uygulandığını görmekteyiz. Bizim yaptığımız onlann zamanında gerekmeyen ve gereksinim duyulmayan diğer âyetlerin aynı iki tür anlayışa göre anlaşılmasına gidilmesinin bin dört yüz yıl sonra, günümüzde ve gelecekte Müslümanlara daha kolay Müslümanlıklarını yaşama imkânı sağlayacağından şüphe olmamalıdır. Üzerimize düşenden yapabileceğimizi biz yaparız ve bizden sonrakilere, ilk Müslümanların örneklerini taşımış ve göstermiş oluruz. Bizden başkasının da kendisine düşeni en iyi şekilde yapabileceğinden kuşku duymamak gerekir. 